Article

\title{
Hydrochemical Characteristics, Controlling Factors, and Solute Sources of Streamflow and Groundwater in the Hei River Catchment, China
}

\author{
Yongchao Kou, Zhou Li, Kun Hua ${ }^{\mathbb{D}}$ and Zhi Li *(D) \\ College of Natural Resources and Environment, Northwest A\&F University, Yangling 712100, China; \\ chao3096@126.com (Y.K.); 15353547583@163.com (Z.L.); huakun@ceiet.com (K.H.) \\ * Correspondence: lizhibox@nwafu.edu.cn
}

Received: 28 August 2019; Accepted: 31 October 2019; Published: 1 November 2019

check for updates

\begin{abstract}
Water scarcity in arid regions is exacerbated by water quality degradation from anthropogenic contamination. In water-scarce regions, it is crucial to identify hydrochemical characteristics and pollution sources for effective water resource management. In this study, the Hei River-located in the Loess Plateau of China, which is an arid region with substantial anthropogenic-induced environmental changes-was selected as the study area to investigate these issues. The major ions of 242 streamflow and groundwater samples were measured during the 2014 and 2015 dry and flood seasons. Using a Piper diagram, a fuzzy membership function, a Gibbs diagram, and a forward model, the hydrochemical facies and water quality of streamflow and groundwater were investigated, and the main river solute sources and relative contributions were determined using quantitative and qualitative methods. The total dissolved solids were $279.6 \pm 127.8 \mathrm{mg} \cdot \mathrm{L}^{-1}$ for streamflow and $354.0 \pm 157.4 \mathrm{mg} \cdot \mathrm{L}^{-1}$ for groundwater, indicating low salinity water. However, the hydrochemical characteristics varied with season and location. Qualitatively, the atmospheric inputs, human activities, and rock weathering all contributed solutes to the waters but with varying contributions. The following are the mean contributions of analyzed solute source: silicate weathering $(45.1 \pm 1.1 \%)>$ carbonate weathering $(34.1 \pm 1.6 \%)>$ evaporite dissolution $(13.7 \pm 2.4 \%)>$ atmospheric input $(5.4 \pm 0.1 \%)>$ anthropogenic input $(1.7 \pm 0.1 \%)$. In general, water quality was satisfactory, as the majority of samples conformed to drinking water standards. The samples had good water quality because the river solutes were not heavily affected by anthropogenic activities and were primarily controlled by rock weathering. However, localized areas of high anthropogenic impact were identified. Such locations should be prioritized for pollution control and water resource management.
\end{abstract}

Keywords: water quality; controlling factors; forward model; water resources management

\section{Introduction}

Long-term focus on water problems has generally related to water quantity; however, since the 1990s, water pollution from human activities has increasingly threatened the majority of rivers $[1,2]$. Consequently, arid and semiarid regions are threatened by both limited water supply and water quality deterioration [3,4]. Water quality deterioration indirectly reduces the amount of available water, and thus exacerbates the water shortage crisis in arid regions [5,6]. As such, there is an urgent need to develop appropriate water resource management strategies for arid regions, considering the well-understood causes of water pollution.

To identify pollution sources, it is useful to analyze the hydrochemical characteristics of rivers and groundwater and investigate major solute sources. The dissolved load compositions of the streamflow and groundwater in a catchment area are derived from a variety of natural and artificial processes $[7,8]$. 
Natural processes include atmospheric inputs and chemical weathering of silicates, carbonates, and evaporites. Anthropogenic discharge may include untreated domestic water, urban rainwater, and cultivated and returned water [9]. However, multiple discharge sources to river and groundwater systems can complicate the identification of ion sources. Consequently, a combination of qualitative and quantitative methods must be used to accurately identify and distinguish between the various ion sources.

The Loess Plateau in China exhibits severe soil erosion due to its steep slopes, low vegetation coverage, loose loess, and concentrated rainfall [10]. Thus far, extensive engineering and biological measures have been implemented to reduce soil and water loss. Consequently, the land use structure has been substantially changed by converting steep farmlands to grasslands or forestlands; simultaneously, large areas of farmland have been converted to apple orchards for income improvement [11,12]. With these changes in surface conditions, soil erosion has been effectively reduced; however, river flow has significantly reduced as well, threatening the sustainability of the region $[13,14]$. Despite the direct reduction of water quantity, fertilizer application strategies because of land use change also influence water quality [15-17]. As such, investigations of water quality are important, especially considering recent anthropogenic-induced environmental change. However, previous studies on water chemistry in the Loess Plateau have been predominantly based on single sampling or limited river cross section sampling $[4,18]$. Without sufficient data, it is difficult to characterize temporal and spatial changes in hydrochemical characteristics at the catchment scale.

To improve our understanding of water quality in response to recent anthropogenic-induced environmental change in the Loess Plateau, the Hei River was chosen as a case study area in which to collect water samples in the dry and flood seasons of 2014 and 2015 to analyze water quality and solute sources. Specifically, we asked the following questions: (i) How do hydrochemical characteristics and water quality vary spatiotemporally? (ii) Where do the dissolved solutes come from? (iii) What is the implication for water resource management? To answer these questions, we collected 242 water samples from various river locations and throughout different seasons to identify spatial and temporal patterns of hydrochemistry. After determining the main ion concentrations, the fuzzy membership function was applied to analyze streamflow and groundwater water quality. Furthermore, stoichiometry, Piper and Gibbs diagram, and a forward model were used to qualitatively and quantitatively identify the contributions of different endmembers (e.g., rock weathering, atmospheric inputs, and anthropogenic activities) of solute sources to the river. The results of this study have major implications for water resource management throughout the Loess Plateau and similar regions with substantially changed environmental conditions.

\section{Materials and Methods}

\subsection{Study Area}

The Hei River is located in the southern part of the Loess Plateau (Figure 1). The river has a length of $168 \mathrm{~km}$ and the watershed has an area of $1506 \mathrm{~km}^{2}$. The catchment experiences a sub-humid and temperate continental monsoon climate. The annual mean precipitation is $555.7 \mathrm{~mm}$ and the annual mean temperature is $9.4^{\circ} \mathrm{C}$ [10]. More than $55 \%$ of the annual rainfall occurs between July and September in the form of rainstorms. The elevation decreases from west to east, ranging from 2459 to $1000 \mathrm{~m}$. The lower reaches of the Hei River, located in a typical tableland-gully region of the Loess Plateau, are dominated by flat tablelands covered by $150 \mathrm{~m}$ thick loess deposits. These deposits store large amounts of subsurface water, and the loess sequence from top to bottom includes deposits such as the Malan, Lishi, and Wucheng, where the Lishi and Wucheng loess act as an aquifer and aquitard, respectively. Gullies dominate the upper reaches of the Hei River and deeply undercut the bedrock. 


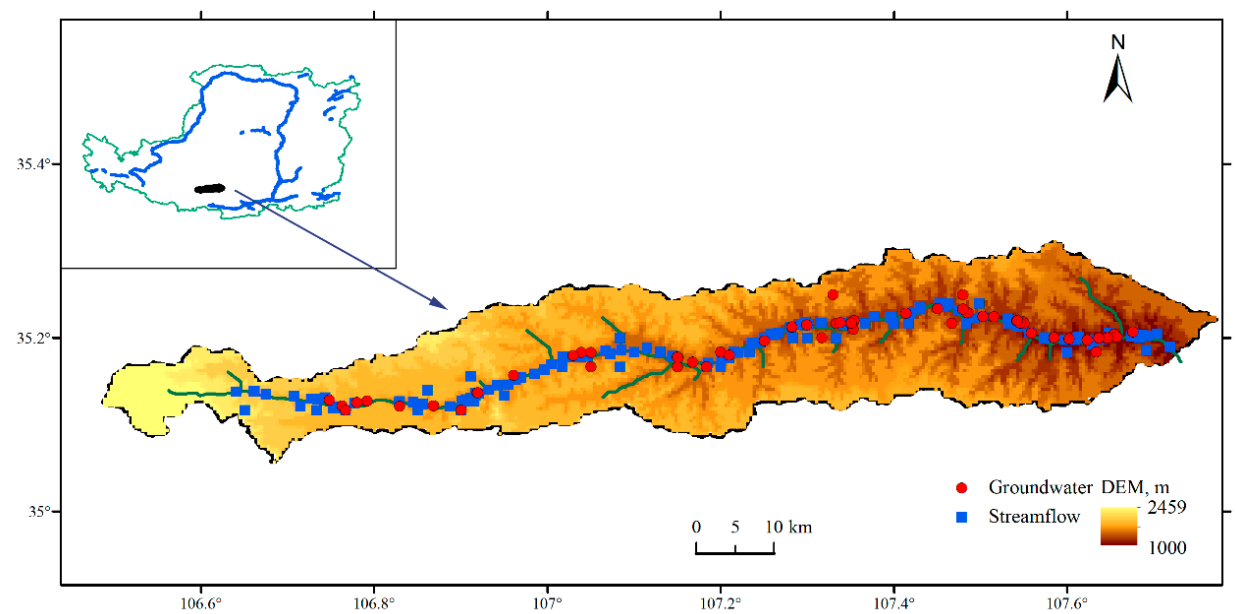

Figure 1. Sampling sites of streamflow and groundwater along the Hei River. DEM, Digital Elevation Model.

The relative contributions of rainfall and groundwater to the streamflow are characterized by seasonal and spatial variability in the river catchment, whereby contributions from groundwater are highest along the downstream reaches of the river [19]. Spatial variability in topography and its effects on the resulting flow paths may also affect the hydrochemical characteristics of the streamflow. Furthermore, as an agricultural watershed, where farmland, grassland, and forests account for $58 \%$, $36 \%$, and $5 \%$ of the total area, respectively [10], fertilizer application likely has a significant effect on streamflow hydrochemistry.

\subsection{Sampling and Analysis}

To reflect seasonal and spatial variabilities in hydrochemistry, streamflow and groundwater (from wells or springs) samples were collected along the river during both the dry (June) and flood (September) seasons in 2014 and 2015. Based on the relationship between precipitation and evapotranspiration, the months of June and September reflected the dry and flood seasons, respectively [19]. We collected 51 (June 2014), 45 (September 2014), 88 (June 2015), and 58 (September 2015) samples during the four sampling campaigns. Prior to sample collection, to ensure the collection of fresh groundwater, well groundwater was first pumped for approximately $30 \mathrm{~min}$. The $\mathrm{pH}$ and total dissolved solids (TDS) were measured in situ using a portable multi-parameter meter (SG78-FK-CN, Mettler Toledo). Water samples were stored in $150 \mathrm{~mL}$ polyethylene bottles at $0-4{ }^{\circ} \mathrm{C}$.

The cation concentrations, including $\mathrm{K}^{+}, \mathrm{Na}^{+}, \mathrm{Ca}^{2+}$, and $\mathrm{Mg}^{2+}$, were determined using coupled plasma-atomic emission spectrometry (ICP-AES) with a relative standard deviation (RSD) of $<1 \%$. The anion concentrations, including $\mathrm{Cl}^{-}, \mathrm{SO}_{4}{ }^{2-}$, and $\mathrm{NO}_{3}{ }^{-}$, were determined by ion chromatography (DIONEX ICS-1100, Thermal Fisher Scientific, USA) with a detection limit of $0.1 \mathrm{ppm}$. The $\mathrm{HCO}_{3}{ }^{-}+$ $\mathrm{CO}_{3}{ }^{2-}$ content in water samples was inversely calculated using the ion balance method [20].

\subsection{Data Analysis}

First, spatiotemporal patterns were analyzed to determine hydrochemical characteristics, dominant water types, and water quality using geochemical data from the four sampling campaigns. Second, the controlling factors of the dissolved solutes were qualitatively and quantitatively analyzed. The main ions, hydrochemical facies, and sources of dissolved solutes were interpreted using a Piper diagram [21]. The fuzzy membership function was then used to evaluate the water quality according to the Environmental Quality Standard for Surface Water in China (Table 1); a previous study reported the detailed procedures and water quality standards used in this method. 
Table 1. The standards used for the water quality evaluation. The parameters are the overlapped data from our measurements and those from the Environmental Quality Standards for Surface Water in China. TDS: total dissolved solids.

\begin{tabular}{cccccc}
\hline Class & $\mathbf{C l}^{-}$ & $\mathbf{S O}_{4}{ }^{2-}$ & $\mathbf{N O}_{3}{ }^{-}$ & TDS & Suitability \\
\hline I & 50 & 50 & 8.9 & 300 & $\begin{array}{c}\text { Drinking, } \\
\text { aquiculture } \\
\text { Drinking, } \\
\text { aquiculture } \\
\text { Drinking, }\end{array}$ \\
II & 150 & 150 & 22.1 & 500 & $\begin{array}{c}\text { aquiculture } \\
\text { Industry }\end{array}$ \\
III & 250 & 250 & 88.6 & 1000 & Irrigation \\
IV & 350 & 350 & 132.9 & 2000 & 2000 \\
V & 350 & 350 & 132.9 & & \\
\hline
\end{tabular}

The Gibbs diagram was used to qualitatively analyze the factors controlling the dissolved solutes and to identify the roles that atmospheric inputs, rock weathering, evaporite dissolution, and anthropogenic activities play regarding river chemistry [22]. Furthermore, a forward model was used to separate the relative contribution of each source [23]. The mass balance equation for any element, $X$, in the dissolved load can be expressed as follows:

$$
[\mathrm{X}]_{\mathrm{ws}}=[\mathrm{X}]_{\mathrm{atm}}+[\mathrm{X}]_{\mathrm{anth}}+[\mathrm{X}]_{\mathrm{carb}}+[\mathrm{X}]_{\mathrm{sil}}+[\mathrm{X}]_{\mathrm{eva}}
$$

where ws is the water sample, atm is the atmospheric input, anth is the anthropogenic input, sil is silicate weathering, carb is carbonate weathering, and eva is evaporite dissolution. Detailed calculations for the forward modeling can be found in a previous study [4].

\section{Results}

\subsection{River Hydrochemical Characteristics}

The mean and standard deviation of the hydrochemical parameters for both the streamflow and groundwater are listed in Table 2. Both streamflow and groundwater were weakly alkaline, with $\mathrm{pH}$ ranges of 8.13-9.19 and 7.11-8.51, respectively. Although both are freshwater flows, the average TDS range was $279.6 \pm 127.8$ and $354.0 \pm 157.4 \mathrm{mg} \mathrm{L}^{-1}$ (mean $\pm \mathrm{sd}$ ), respectively. The dominant cation concentrations had an order of $\mathrm{Na}^{+}>\mathrm{Ca}^{2+}>\mathrm{Mg}^{2+}>\mathrm{K}^{+}$, while the dominant anion concentrations had an order of $\mathrm{HCO}_{3}{ }^{-}>\mathrm{SO}_{4}{ }^{2-}>\mathrm{Cl}^{-}>\mathrm{NO}_{3}{ }^{-}$. Sodium dominated the cations in both the streamflow and groundwater, accounting for $45-72 \%$ and $45-73 \%$ of the total cation concentrations, respectively. Bicarbonate dominated the anions in both the streamflow and groundwater, accounting for $41-54 \%$ and $41-49 \%$ of the total anion concentrations, respectively.

Table 2. The mean and standard deviation (STD) of the ion concentrations in the streamflow and groundwater.

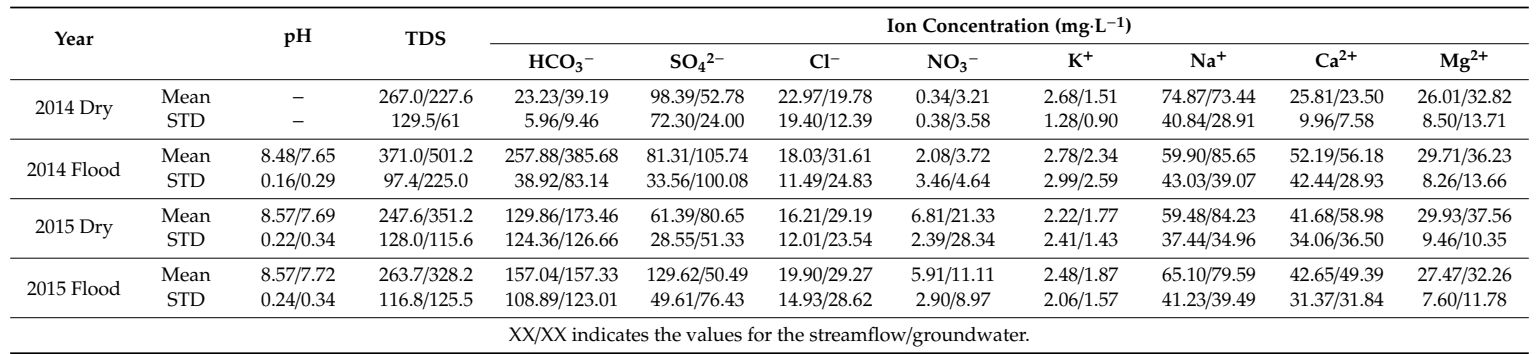

The concentrations of most ions exhibited similar trends to the TDS; thus, we assessed the spatiotemporal patterns of hydrochemistry using TDS (Figure 2). In the dry season, the streamflow TDS was characterized by high fluctuations in the upper and middle reaches of the Hei River, but gradually 
increased downstream into the lower reaches. Comparatively, the TDS gradually increased downstream during the flood season (Figure 2a). For groundwater, TDS increased downstream regardless of the season (Figure 2b). The groundwater TDS concentrations in 2014 and 2015 were similar for both the dry and flood seasons, suggesting low interannual variability in major ion concentrations.

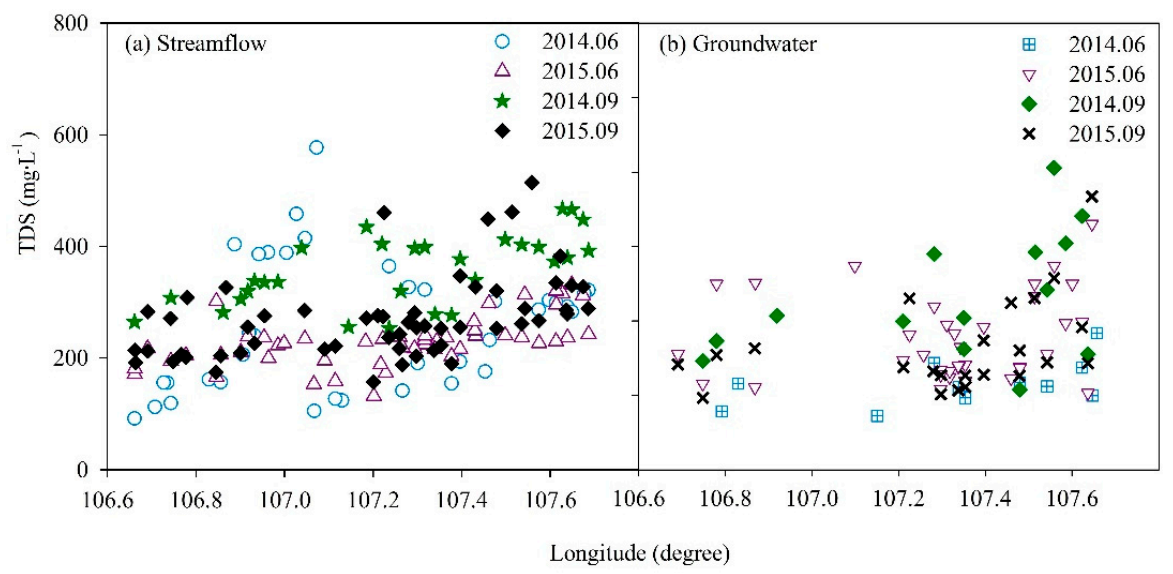

Figure 2. Spatial variations in the streamflow and groundwater TDS from 2014-2015.

\subsection{Hydrochemical Facies and Water Quality}

We plotted the streamflow and groundwater data points from the different sampling campaigns

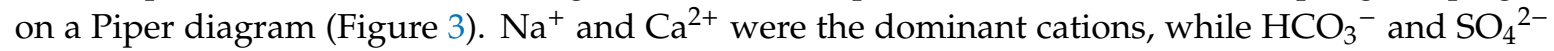
were the dominant anions in both the streamflow and groundwater. However, the dominant ions varied with the season. Specifically, the dominant cation and anion in the dry season were $\mathrm{Na}^{+}$and $\mathrm{SO}_{4}{ }^{2-}$, respectively, while the dominant cation and anion in the flood season were $\mathrm{Ca}^{2+}$ and $\mathrm{HCO}_{3}{ }^{-}$. Accordingly, the dominant hydrological facies in the dry season were $\mathrm{Ca}-\mathrm{Mg}-\mathrm{SO}_{4}-\mathrm{Cl}$ and $\mathrm{Na}-\mathrm{SO}_{4}-\mathrm{Cl}$, whereas the dominant hydrological facies in the flood season was $\mathrm{Ca}-\mathrm{Mg}-\mathrm{HCO}$. Furthermore, the hydrochemistry of the streamflow and groundwater samples overlapped in different periods, suggesting an influence from similar hydraulic processes in both water flows.

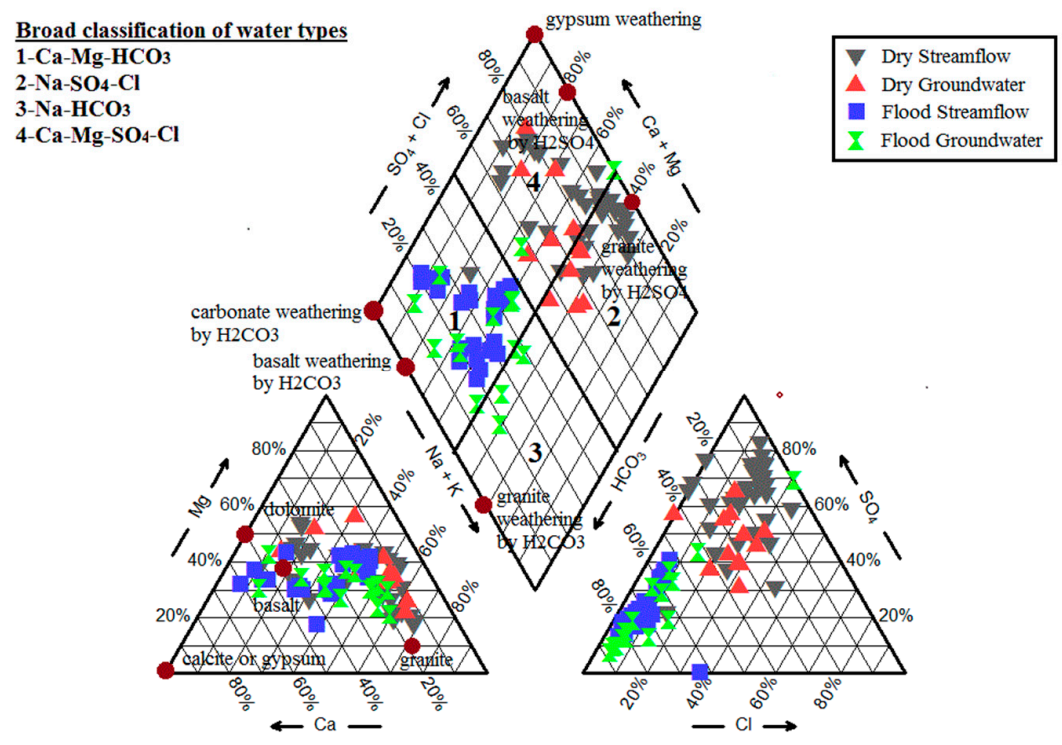

Figure 3. Piper diagram of the anions and cations in the Hei River.

Using water quality standards and our measurements, we categorized the water quality into five classes by applying the fuzzy membership function. Over $97 \%$ of the water samples belonged in class I to III, and were therefore considered satisfactory with respect to water quality standards. Spatially, 
class III water samples were predominantly located in the upper and middle reaches of the Hei River (Figure 4). Water samples from the upper and middle reaches were similar in quality to those from the lower reaches of the river for two potential reasons: first, river pollutant discharge originated from coal mining and washing sites located in the upper and middle reaches and, secondly, higher flow rates or water volume in the lower reaches could dilute pollutant concentrations in the dissolved load of the river water.

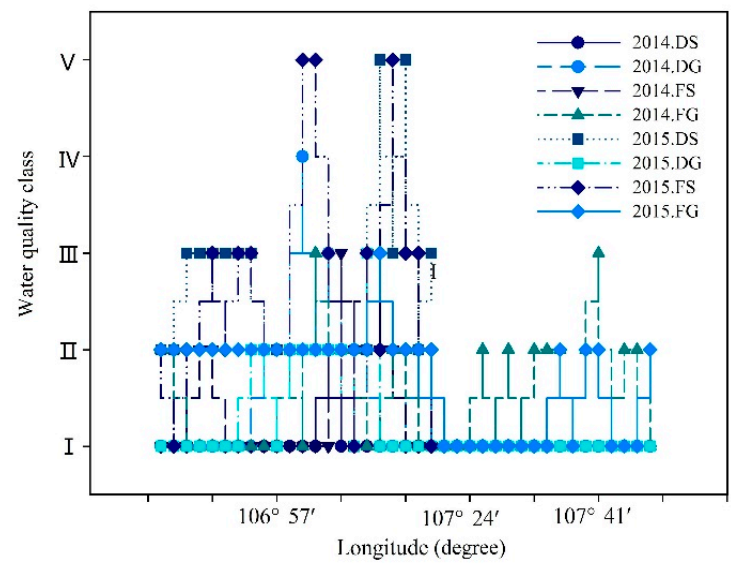

Figure 4. The spatial patterns in the streamflow and groundwater quality in the Hei River. In the legend, 2014 and 2015 represent years of sample collection. D and F represent the seasons in which samples were collected: dry or flood season, respectively. S and G represent streamflow and groundwater, respectively.

\section{Discussion}

\subsection{Factors Controlling Dissolved Solutes}

\subsubsection{Processes Controlling River Solutes}

Since most water samples fell within the Gibbs diagram (Figure 5), it is unlikely that anthropogenic activities significantly influenced solute concentrations in this river [24]. Rather, most hydrochemical parameters fell within the fields defined by $\mathrm{Na}^{+} /\left(\mathrm{Na}^{+}+\mathrm{Ca}^{2+}\right)$ or $\mathrm{Cl}^{-} /\left(\mathrm{Cl}^{-}+\right.$ $\mathrm{HCO}_{3}{ }^{-}$) endmembers, which suggests that the river chemistry is predominantly affected by rock weathering [25]. The average streamflow $\mathrm{Cl} / \mathrm{Na}$ value of 0.3 was much lower than the average global seawater ratio $(\mathrm{Cl} / \mathrm{Na}=1.15)$, which indicates that there were minimal contributions from sea salt transported by atmospheric circulation.
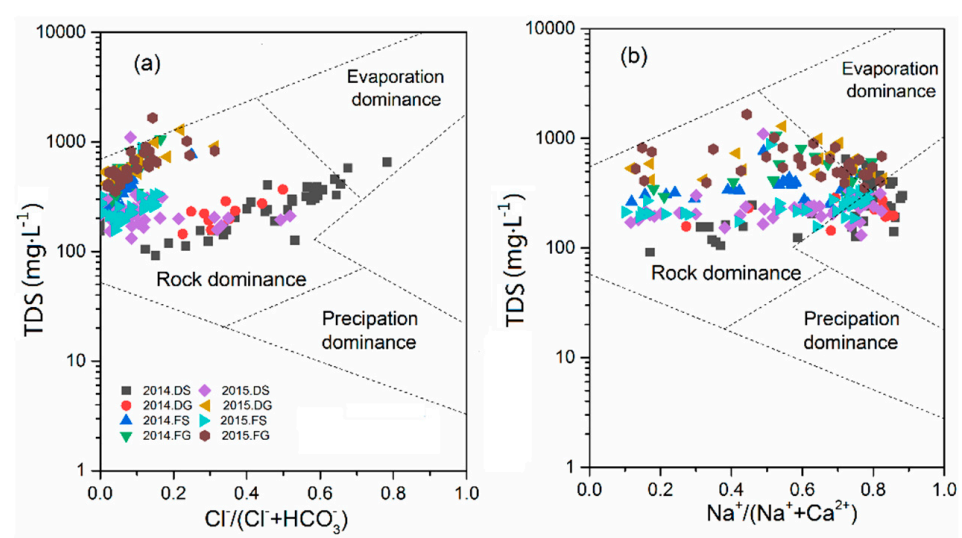

Figure 5. Gibbs diagram of the water samples collected during the dry and flood seasons: (a) anion ratios and (b) cation ratios. In the legend, 2014 and 2015 represent years of sample collection. D and F represent the seasons in which samples were collected: dry or flood season, respectively. S and G represent streamflow and groundwater, respectively. 


\subsubsection{Stoichiometric Analysis of Streamflow}

Stoichiometric solute ratios can be effectively used to track their sources [9]. If $\mathrm{Na}^{+}$derives predominantly from rock salt dissolution (evaporites), the $\mathrm{Na} / \mathrm{Cl}$ equivalence ratio should be close to 1:1 [26]. However, the majority of the data points in this study fell above the 1:1 line (Figure 6a), indicating the additional input of $\mathrm{Na}^{+}$from either sodium aluminosilicate $\left(\mathrm{NaAlSi}_{3} \mathrm{O}_{8}\right)$ weathering or anthropogenic inputs. The weathering of carbonate rocks or evaporites yields $\mathrm{Ca}^{2+}, \mathrm{Mg}^{2+}$, and $\mathrm{SO}_{4}{ }^{2-}$ [4]. If $\mathrm{Ca}^{2+}$ and $\mathrm{Mg}^{2+}$ derive predominantly from carbonate weathering, the equivalence ratio of $\left(\mathrm{Ca}^{2+}+\mathrm{Mg}^{2+}\right) / \mathrm{HCO}_{3}{ }^{-}$should be close to 1:1 [27]. However, the majority of our samples fell above the 1:1 line during the dry season (Figure 6b), indicating additional impacts from exogenous acids. This suggests either that $\mathrm{Cl}^{-}$and $\mathrm{SO}_{4}{ }^{2-}$ balanced excessive $\mathrm{Ca}^{2+}$ and $\mathrm{Mg}^{2+}$ during the dry season, or that $\mathrm{Na}^{+}$and $\mathrm{K}^{+}$balanced the alkalinity of the river. In contrast, most samples fell close to the 1:1 line in the flood season, suggesting that carbonate weathering was the main source of $\mathrm{Ca}^{2+}$ and $\mathrm{Mg}^{2+}$ at these times. Both $\mathrm{Ca}^{2+}+\mathrm{Mg}^{2+}$ and $\mathrm{HCO}_{3}{ }^{-}+\mathrm{SO}_{4}{ }^{2-}$ can indicate the occurrence of carbonate and silicate weathering. Therefore, the strong correlation between $\mathrm{Ca}^{2+}+\mathrm{Mg}^{2+}$ and $\mathrm{HCO}_{3}{ }^{-}+\mathrm{SO}_{4}{ }^{2-}$ indicated contributions from both carbonate and silicate weathering to the riverine solute composition during the flood season (Figure 6c).
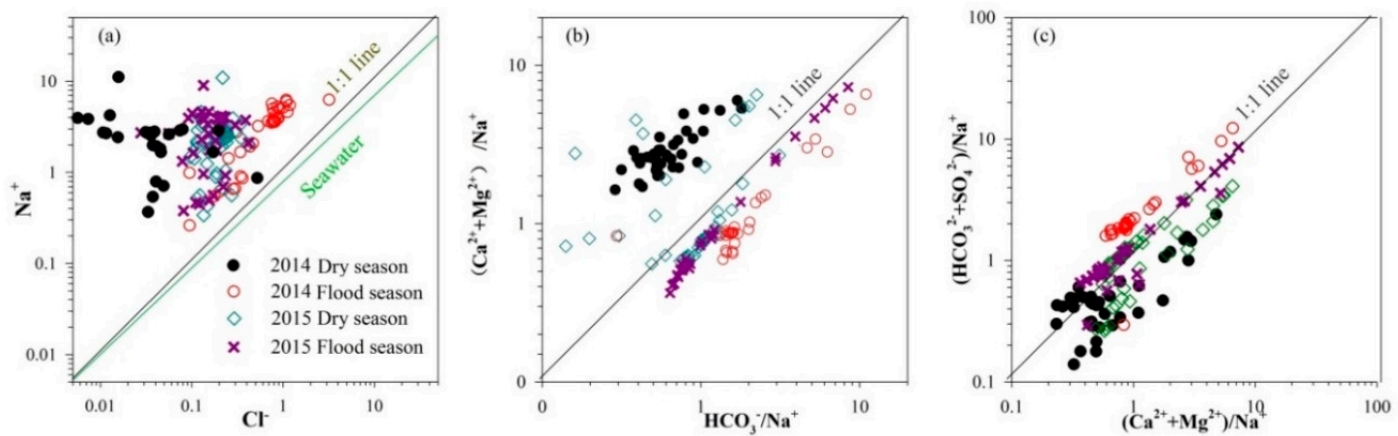

Figure 6. Stoichiometry plots of water samples collected from the Hei River. (a) $\mathrm{Na}^{+} / \mathrm{Cl}^{-}$equivalence ratio. (b) Equivalence ratio of $\left(\mathrm{Ca}^{2+}+\mathrm{Mg}^{2+}\right) / \mathrm{HCO}_{3}{ }^{-}$. (c) Equivalence ratio of $\left(\mathrm{Ca}^{2+}+\mathrm{Mg}^{2+}\right) /\left(\mathrm{HCO}_{3}{ }^{-}\right.$ $\left.+\mathrm{SO}_{4}{ }^{2-}\right)$.

\subsection{Source Contributions of Dissolved Solutes}

The contributions of different sources (e.g., atmospheric input, anthropogenic input, and rock weathering) to the solutes in the river are listed in Table 3. In general, carbonate and silicate weathering were the primary sources of dissolved solutes in the streamflow. Solute contributions from evaporite dissolution varied between seasons owing to climate variability, contributing $10.9 \pm 1.6 \%$ in the dry season and $16.5 \pm 0.4 \%$ in the flood season. Solute contributions from the atmosphere were higher in the dry season relative to the flood season. Anthropogenic inputs contributed $0.4 \pm 0.1 \%$ and $3.0 \pm 0.2 \%$ to the river solutes in 2014 and 2015, respectively, suggesting a minor contribution towards determining water quality.

Table 3. Contributions of different factors to the dissolved solutes (\%).

\begin{tabular}{cccccc}
\hline Season & $\begin{array}{c}\text { Silicate } \\
\text { Weathering }\end{array}$ & $\begin{array}{c}\text { Carbonate } \\
\text { Weathering }\end{array}$ & $\begin{array}{c}\text { Evaporite } \\
\text { Dissolution }\end{array}$ & $\begin{array}{c}\text { Atmospheric } \\
\text { Input }\end{array}$ & $\begin{array}{c}\text { Anthropogenic } \\
\text { Input }\end{array}$ \\
\hline Dry Season & $47.6 \pm 5.7$ & $32.7 \pm 7.4$ & $10.9 \pm 1.6$ & $7.0 \pm 0.3$ & $1.8 \pm 0.1$ \\
Flood Season & $42.6 \pm 0.4$ & $35.6 \pm 0.8$ & $16.5 \pm 0.4$ & $3.7 \pm 0.2$ & $1.6 \pm 0.2$ \\
All & $45.1 \pm 1.1$ & $34.1 \pm 1.6$ & $13.7 \pm 2.4$ & $5.4 \pm 0.1$ & $1.7 \pm 0.1$ \\
\hline
\end{tabular}




\subsubsection{Atmospheric Inputs}

Riverine $\mathrm{Cl}^{-}$originates predominantly from sea salt aerosols and atmospheric dust [23], the concentrations of which decrease with increasing distance from the ocean [28]. Measurements of ionic concentrations in rainwater were collected from one site within the East Asia Acid Rain Network near the study area (Table 4). The ratio of $\mathrm{TZ}^{+}$from atmospheric inputs ranged between $2.7 \%$ and $7.4 \%$. Atmospheric contributions to river solutes were larger in the dry season, with two potential reasons (Table 3): (1) Streamflow runoff is lower during the dry season while evaporation is higher, and (2) local air pollution is more severe during the dry season.

Table 4. Chemical composition of the rainwater samples.

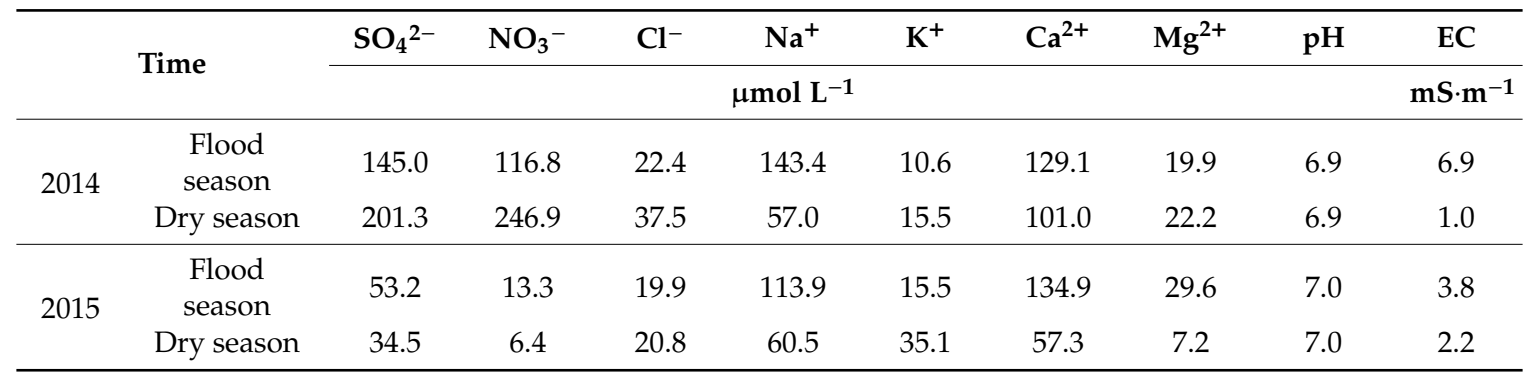

\subsubsection{Anthropogenic Inputs}

Anthropogenic activities can affect the major ion concentrations in water either directly, through the discharge of fertilizers and untreated waste water, or indirectly, by changing the underlying surface conditions [29]. Higher $\mathrm{NO}_{3} / \mathrm{Na}$ ratios compared with $\mathrm{Cl} / \mathrm{Na}$ ratios indicate increased contributions of effluent discharge to a river [30]. However, most water samples in this study fell below the 1:1 line for $\mathrm{NO}_{3} / \mathrm{Na}$ versus $\mathrm{Cl} / \mathrm{Na}$ (Figure 7), indicating that anthropogenic sources have a minor impact on river chemistry. In addition, only 5 out of the 242 water samples had $\mathrm{NO}_{3}-\mathrm{N}$ contents higher than $10 \mathrm{mg}$ $\mathrm{L}^{-1}$, the drinking water standard set by the World Health Organization, providing further evidence for the minor impacts of human activities. The forward model demonstrated that the contributions of anthropogenic activities in the flood and dry seasons in 2015 were $3.4 \%$ and $2.6 \%$, respectively, higher than the respective contributions of $0.2 \%$ and $0.5 \%$ in 2014 . These minimal contributions predominantly derive from agriculture and are due to the expansion of farmland in the study area [11].

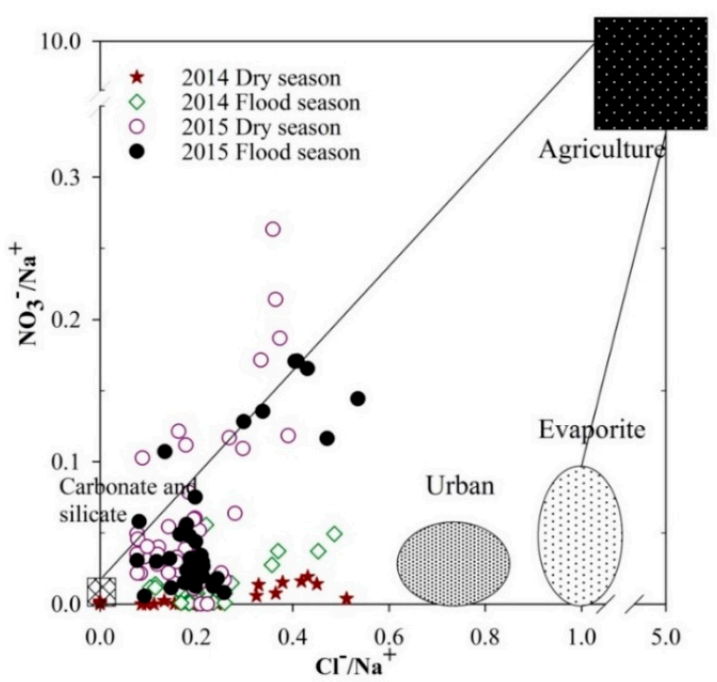

Figure 7. $\mathrm{Cl} / \mathrm{Na}$ versus $\mathrm{NO}_{3} / \mathrm{Na}$ ratios. Data for the evaporite and agricultural endmembers were obtained from Roy et al. (1999), and from Lang et al. (2006) and Chetelat et al. (2008) for the urban endmember. 


\subsubsection{Rock Weathering}

According to the Gibbs diagram, rock weathering was the main control on riverine solutes (Figure 5). In agreement with this result, the Piper diagram showed that most samples were concentrated in the silicate (basalt and granite), carbonate weathering, and evaporite salt (gypsum) fields (Figure 3). In general, halite $\left(\mathrm{Na}^{+}: \mathrm{Cl}^{-}=1: 1\right)$, gypsum $\left(\mathrm{CaSO}_{4} \cdot 2 \mathrm{H}_{2} \mathrm{O}\right)$, and/or anhydrite were the principal sources of $\mathrm{SO}_{4}{ }^{2-}$ and $\mathrm{Cl}^{-}$. Other than atmospheric inputs, $\mathrm{Cl}^{-}$concentrations in streamflow were mainly derived from rock weathering. In addition to the hydrolysis of gypsum, the oxidation of pyrite can also be a source of $\mathrm{SO}_{4}{ }^{2-}$.

The estimated contributions from silicate, carbonate, and evaporite dissolution were $39.3-52.7 \%$, $30.0-37.0 \%$, and $4.3-21.1 \%$, respectively. The mean contribution of the different weathering sources had an order of silicate weathering $>$ carbonate weathering $>$ evaporite dissolution, owing to the fact that the surrounding lithology is enriched in silicates (such as felspar, plagioclase, and pyroxenes) relative to carbonates and evaporites [31]. However, the contribution rates of the different rock sources varied between seasons (Table 3). For instance, we observed higher contributions from carbonate weathering and evaporite dissolution in the flood season ( $35.6 \pm 0.8 \%$ and $16.5 \pm 0.4 \%$, respectively) relative to the dry season $(32.7 \pm 7.4 \%$ and $10.9 \pm 1.6 \%$, respectively), since carbonate weathering and evaporite dissolution are more sensitive to hydrothermal conditions [32]. In contrast, silicate weathering occurred in the dry season because slower flow rates extend the interaction time between water and silicate rock. Overall, carbonate and silicate weathering were the primary sources of streamflow ions, accounting for $75.9-81.1 \%$ of the riverine solutes.

\subsection{Implications for Water Resource Management}

The overall water quality in the study area was found to be good, meeting the relevant standards for drinking water and agricultural water use. The water quality of the Hei River is better than that of other rivers on the Loess Plateau. For example, our previous study showed that over $30 \%$ of streamflow or groundwater samples from the Wei River had water quality of Class V in the wet season [15]; the Fen River had even worse water quality [16]. The dissolved solutes in this river mostly come from rock weathering, and the effect of human activities is different than that in other rivers [4]. Specifically, the Wei and Fen rivers support large areas of farmlands, a large population, and an industrial base, while the Hei River is much smaller, with anthropogenic inputs mostly from agriculture and coal mining. As such, pollutant control for the Hei River should focus on fertilizer application strategies and management of wastewater from coal mining.

In addition, because of land use change and climate variability, streamflow has been decreasing in recent decades, and will probably continue to decrease in the future $[10,33]$. As decreasing water volume will contribute to the enrichment of pollutants in waters, urgent measures are needed to adjust the hydrological cycle. With these considerations, the land use pattern should be adjusted considering future sustainability under climate change. A minimal streamflow able to sustain the local ecology, civil water demand, and good water quality should be defined.

\section{Conclusions}

To analyze the water quality and pollution sources in a river with substantial environmental changes, the ion concentrations of 242 streamflow and groundwater samples collected from the Hei River in the Loess Plateau were measured. Samples were collected in both the dry and wet seasons, covering different reaches of the river to reflect spatiotemporal variability in river hydrochemistry. Overall, the streamflow and groundwater were weakly alkaline and had low salinity, with dominant anion and cation of $\mathrm{Na}^{+}$and $\mathrm{HCO}_{3}{ }^{-}$, respectively. The overall water quality was good for most water samples, since streamflow hydrochemistry was primarily influenced by rock weathering with only minor effects from anthropogenic activities. Contributions from silicate and carbonate weathering dominated the riverine solutes, with fractional contributions of $75.9 \%-81.1 \%$. Although atmospheric inputs and 
anthropogenic activities have had relatively minor effects on the riverine solutes, some localized areas subject to concentrated anthropogenic impact were identified; these areas should be the focus for pollution control and water resource management. In arid regions, limited water quantity is a key factor in regional development; however, the anthropogenic-induced deteriorated water quality will further worsen the situation. As such, the hot spot, hot moment, and pollutant sources of water pollution should be identified for pollution control.

Author Contributions: Z.L. (Zhi Li) designed this study, and wrote and edited the manuscript. Y.K. did sample collection and analysis, and finished the first manuscript. Z.L. (Zhou Li) and K.H. finished the figures and edited the manuscript.

Funding: This research was supported by the International Partnership Program of the Chinese Academy of Sciences (161461KYSB20170013) and the State Key Joint Laboratory of Environment Simulation and Pollution Control (K20180601).

Conflicts of Interest: The authors declare no conflict of interest.

\section{References}

1. United Nation Environment Programme. A Snapshot of the World's Water Quality: Towards a Global Assessment; United Nations Environment Programme: Nairobi, Kenya, 2016; p. 162.

2. Liu, J.; You, L.; Amini, M.; Obersteiner, M.; Herrero, M.; Zehnder, A.J.B.; Yang, H. A high-resolution assessment on global nitrogen flows in cropland. Proc. Natl. Acad. Sci. USA 2010, 107, 8035-8040. [CrossRef] [PubMed]

3. Noh, H.; Huh, Y.; Qin, J.; Ellis, A. Chemical weathering in the three rivers region of eastern tibet. Geochim. Et Cosmochim. Acta 2009, 73, 1857-1877. [CrossRef]

4. Xiao, J.; Zhang, F.; Jin, Z.D. Spatial characteristics and controlling factors of chemical weathering of loess in the dry season in the middle loess plateau, China. Hydrol. Process. 2016, 30, 4855-4869. [CrossRef]

5. Abdel-Gawad, S.T. Water Quality Challenges Facing Egypt; Springer: Dordrecht, The Netherlands, 2005; pp. 335-347.

6. Zhang, Q.; Zhang, F.; Jin, Z.; Xiao, J. Seasonal variation in river water chemistry of the middle reaches of the Yellow river and its controlling factors. J. Geochem. Explor. 2015, 156, 101-113. [CrossRef]

7. Appelo, C.A.J.; Postma, D. Geochemistry, Groundwater and Pollution, 2nd ed.; Balkema: Rotterdam, The Netherlands, 2004; p. 647.

8. Abdelaziz, R.; Pearson, A.J.; Merkel, B.J. Lattice boltzmann modeling for tracer test analysis in a fractured gneiss aquifer. Nat. Sci. 2013, 5, 368-374. [CrossRef]

9. $\mathrm{Li}, \mathrm{S}$.; $\mathrm{Lu}, \mathrm{X}$.X.; Bush, R.T. Chemical weathering and $\mathrm{CO}_{2}$ consumption in the lower Mekong river. Sci. Total Environ. 2014, 472, 162-177. [CrossRef]

10. Li, Z.; Liu, W.; Zhang, X.; Zheng, F. Impacts of land use change and climate variability on hydrology in an agricultural catchment on the Loess Plateau of China. J. Hydrol. 2009, 377, 35-42. [CrossRef]

11. Li, J.; Peng, S.; Li, Z. Detecting and attributing vegetation changes on China's Loess Plateau. Agric. For. Meteorol. 2017, 247, 260-270. [CrossRef]

12. Peng, S.; Li, Z. Incorporation of potential natural vegetation into revegetation programmes for sustainable land management. Land Degrad. Dev. 2018, 29, 3503-3511. [CrossRef]

13. Feng, X.; Fu, B.; Piao, S.; Wang, S.; Ciais, P.; Zeng, Z.; Lü, Y.; Zeng, Y.; Li, Y.; Jiang, X.; et al. Revegetation in China's Loess Plateau is approaching sustainable water resource limits. Nat. Clim. Chang. 2016, 6, 1019-1022. [CrossRef]

14. Wang, S.; Fu, B.; Piao, S.; Lu, Y.; Ciais, P.; Feng, X.; Wang, Y. Reduced sediment transport in the Yellow river due to anthropogenic changes. Nat. Geosci. 2016, 9, 38-41. [CrossRef]

15. Li, Z.; Xiao, J.; Evaristo, J.; Li, Z. Spatiotemporal variations in the hydrochemical characteristics and controlling factors of streamflow and groundwater in the Wei river of China. Environ. Pollut. 2019, 254, 113006. [CrossRef] [PubMed]

16. Hua, K.; Xiao, J.; Li, S.; Li, Z. Analysis of hydrochemical characteristics and their controlling factors in the Fen river of China. Sustain. Cities Soc. 2020, 52, 101827. [CrossRef] 
17. Meng, Z.; Yang, Y.; Qin, Z.; Huang, L. Evaluating temporal and spatial variation in nitrogen sources along the lower reach of Fenhe river (Shanxi province, China) using stable isotope and hydrochemical tracers. Water 2018, 10, 231. [CrossRef]

18. Su, H.; Wang, J.; Liu, J. Geochemical factors controlling the occurrence of high-fluoride groundwater in the western region of the ordos basin, northwestern China. Environ. Pollut. 2019, 252, 1154-1162. [CrossRef]

19. Li, Z.; Lin, X.; Xiang, W.; Chen, X.; Huang, T. Stable isotope tracing of headwater sources in a river on China's Loess Plateau. Hydrol. Sci. J. 2017, 62, 2150-2159. [CrossRef]

20. Mitamura, O.; Seike, Y.; Kondo, K.; Goto, N.; Anbutsu, K.; Akatsuka, T.; Kihira, M.; Tsering, T.Q.; Nishimura, M. First investigation of ultraoligotrophic alpine lake Puma Yumco in the pre-himalayas, China. Limnology 2003, 4, 167-175. [CrossRef]

21. Piper, A.M. A graphic procedure in the geochemical interpretation of water-analyses. Eos Trans. Am. Geophys. Union 1944, 25, 27-39. [CrossRef]

22. Gibbs, R.J. Mechanisms controlling world water chemistry. Science 1970, 170, 1088-1090. [CrossRef]

23. Moon, S.; Huh, Y.; Qin, J.; Pho, N.V. Chemical weathering in the Hong (Red) river basin: Rates of silicate weathering and their controlling factors. Geochim. Cosmochim. Acta 2007, 71, 1411-1430. [CrossRef]

24. Bonotto, D.M.; Lima, J.L.N.D. Hydrochemistry and weathering rates on Corumbataí river basin, São Paulo State, Brazil. J. Hydrol. 2010, 383, 291-306. [CrossRef]

25. Al-Shaibani, A.M. Hydrogeology and hydrochemistry of a shallow alluvial aquifer, western Saudi Arabia. Hydrogeol. J. 2008, 16, 155-165. [CrossRef]

26. Dalai, T.K.; Krishnaswami, S.; Sarin, M.M. Major ion chemistry in the headwaters of the Yamuna river system: Chemical weathering, its temperature dependence and $\mathrm{CO}_{2}$ consumption in the Himalaya. Geochim. Cosmochim. Acta 2002, 66, 3397-3416. [CrossRef]

27. Jacobson, A.D.; Blum, J.D.; Walter, L.M. Reconciling the elemental and sr isotope composition of Himalayan weathering fluxes: Insights from the carbonate geochemistry of stream waters. Geochim. Et Cosmochim. Acta 2002, 66, 3417-3429. [CrossRef]

28. Chen, J.; Wang, F.; Xia, X.; Zhang, L. Major element chemistry of the changjiang (Yangtze river). Chem. Geol. 2002, 187, 231-255. [CrossRef]

29. Chetelat, B.; Liu, C.-Q.; Zhao, Z.; Wang, Q.; Li, S.; Li, J.; Wang, B. Geochemistry of the dissolved load of the changjiang basin rivers: Anthropogenic impacts and chemical weathering. Geochim. Cosmochim. Acta 2008, 72, 4254-4277. [CrossRef]

30. Gaillardet, J.; Dupré, B.; Louvat, P.; Allegre, C. Global silicate weathering and $\mathrm{CO}_{2}$ consumption rates deduced from the chemistry of large rivers. Chem. Geol. 1999, 159, 3-30. [CrossRef]

31. Yokoo, Y.; Nakano, T.; Nishikawa, M.; Quan, H. Mineralogical variation of sr-nd isotopic and elemental compositions in loess and desert sand from the central loess plateau in China as a provenance tracer of wet and dry deposition in the northwestern pacific. Chem. Geol. 2004, 204, 45-62. [CrossRef]

32. Meybeck, M. Global chemical weathering of surficial rocks estimated from river dissolved loads. Am. J. Sci. 1987, 287, 401-428. [CrossRef]

33. Li, Z.; Liu, W.; Zhang, X.; Zheng, F. Assessing and regulating the impacts of climate change on water resources in the heihe watershed on the loess plateau of china. Sci. China Earth Sci. 2010, 53, 710-720. [CrossRef]

(C) 2019 by the authors. Licensee MDPI, Basel, Switzerland. This article is an open access article distributed under the terms and conditions of the Creative Commons Attribution (CC BY) license (http://creativecommons.org/licenses/by/4.0/). 